\title{
SALES PROCESS MANAGEMENT OF INSURANCE SERVICES
}

\author{
Daiva JUREVIČIENE் \\ Mykolas Romeris University, Ateities str. 20, LT-08303 Vilnius, Lithuania \\ E-mail: daiva.jureviciene@mruni.eu
}

doi:10.13165/IE-14-8-2-11

\section{Introduction}

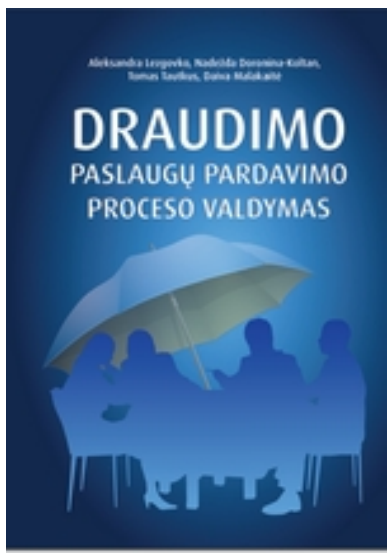

The textbook "Insurance Services sales process management” (authors dr. Aleksandra Lezgovko, Nadežda Doronina-Koltan, Tomas Tautkus, Daiva Malkaitè) is a result of a project implemented by Faculty of Economic and Finance Management of Mykolas Romeris University and Institute of Insurance and Risk Management. The project financed by European Social Fund of „AAS Gjensidige Baltic“ Lithuanian branch staff professional development preparing and implementing non-formal education program "Academy of Insurance" (No VP1-2.2-ŠMM-04-V-06-00) was realized by lectures of Faculty of Economic and Finance Management of Mykolas Romeris University together with ones from Institute of Insurance and Risk Management. The project framed in accordance with Human Resources Development Operational Program Priority 2 "Lifelong Learning” VP12.2-ŠMM-04-V tool „The Highest Quality of Formal and Non-formal Education Services”. It involves insurance company executives, sales managers, consultants-practitioners, sellers. In average 50 percent of employees in all categories during one year (2013) are already trained. As shown by the results of the insurance company during the project (2013) dynamics of insurance premiums increased by 7.67 percent compared to the previous year (2012), from 95 million litas to 103 million litas. 
During the project, there were trained not only employees of the insurance company but also lectures of MRU Faculty of Economic and Finance Management who participated in the training course "Public speaking and communication". The aim of this course is to strengthen the capacity of lectures oratorical, audience management skills, and so on. In addition, two invited professors from Riga and Moscow gave lectures.

\section{Review of the textbook}

Insurance is a concurrent of an advanced economic system that insures protection of all society's social and economic sides, is an important resource for attracting investment into the economy mechanism. The rapid economic development of the country inevitably accompanied by risks increase spectrum and needs of risk assessment, management and expansion of insurance. Insurance services development in Lithuania compared with other European countries is relatively slow and has a great potential to grow. Insurance - an integral part of the financial system but it relates and to the public attitude because not everyone buyer feels the benefits of the insurance service. Unlike other financial services, whose goal is to increase the assets insurance is highly unusual in that thanks to it, one can only protect against possible loss of assets rather, to reduce potential losses due to unexpected event in the future. Therefore, many financial market participants use these services slow hoping "this will not happen to me".

A prerequisite for the insurance market is not only the demand for insurance production but also the presence of insurers able to meet this demand. Unfortunately, the assessments of the insurance market in Lithuania show that insurance recipient (policyholders) insufficiently aware of the insurance services.

This manual describes in detail and consistently one of insurance services branch non-life insurance, which main purpose - to transfer the potential loss due to an adverse event to insurance company in exchange for a fee paid at the time of contract. The insurance service itself is an integral part of the seller so this tutorial focuses on the quality of the sales process, which has both similarities with other sales transactions, as well as differences.

Although "Insurance Services sales process management" is not the first textbook on the insurance topic in Lithuania but it has completeness and includes the analysis of the law regulating the business of insurance, examination of theoretical material in finance, risk management, sales, and comprehensive description of insurance - as a single financial market activity. The authors are insurance professionals, with many years of experience in the insurance market, excellent knowledge of the subtleties of insurance and developed a number of professional insurers.

The textbook consists of the following six parts: Insurance Basics: economic and legal environment; Specifics and characteristics of insurance services; Process of insurance sales; Management of insurance sales process; Management of performance of insurance product sellers'; Advices and digest of risk management and insurance notions. 
The author (Dr. A.Lezgovko, a lecture of Mykolas Romeris University) describe the essence of insurance as a particular financial service, depicts the insurance service and its basic characteristics. A separate section appointed for the introduction of insurance systems, identified its subjects, objects, and the means of achieving goals. A description of all persons involved in the insurance business and their main functions presented. In addition, there is a short description of organizations of insurers and insurance intermediaries' and their priority activities as well as insurance supervision. Considerable attention the author focuses on the legal regulation of the insurance business, which is especially important in this kind of financial service when the buyer, paying the money, do not get the service itself and receive only a "promise" to get it to certain circumstances. A systematic overview of European legislation regulating the insurance business is provided and its transfer to the Lithuanian legal framework. A detailed description of the non-life insurance company's organizational structure, activities, management of the company and limits of employee liability presented.

The authors of the second part (T.Tautkus and D.Malakaite) describe in detail the concept of risk, risk components using inserts with specific examples, classifications of risk. T.Tautkus setting out the process of risk management draws attention to the structure of governance process and process management, but especially focuses on a detailed description of the risk management (management sources, external analysis, analysis of client's situation, detection of threats and vulnerabilities, risk assessment, monitoring, etc.) as well as to risk management philosophy through tables recommended for use (T.Tautkus). D.Malakaitè describing specification of insurance as risk management strategy defines the specifics and characteristics of the insurance service.

The author of the third part (N.Doronina-Koltan) thoroughly illustrates the process of insurance sales including the company's business processes (management and administration, marketing, risk assessment and methodology, sales, services of contracts, management of finance and accounting, human resource management), analysis of interaction of business processes, planning and organization of sales processes, command and control.

The fourth part "Management of insurance sales process" (N.Doronina-Koltan and T.Tautkus) is dedicated to description of the organization of work of insurances service seller, covering every phase and present through the prism of the customers' expectations. This is the description of the application of marketing in the sales process, and risk management, working with insurance clients and technologies of management of sales process stages.

In the fifth part "Management of performance of insurance product sellers" the author (N.Doronina-Koltan) presents basic characteristics of good insurance product seller, how to select and develop a good seller, how to motivate him and control salespersons work.

The authors in the last - the sixth part give examples that facilitate learners to master the material and at the end of the clarification of the definitions of the notions most commonly used in the insurance industry. The textbook material is logical and coherent. 


\section{Conclusions}

E-textbook format advantage is exhausted - in particular, places there are an online active links to the analysed legislations and other referred and analysed sources. The textbook contains particular situations perfectly illustrating the problems that face both the insurance vendors as well as users - this enlivens the provided material, allows the reader to understand better the analysed problem. It must also be noted, and a mandatory attribute of the textbook self-test questions with the correct answers at the end are included that helps students to compare them with their answers. The textbook is vividly illustrated; it provides a number of examples and tables that the reader will be able to use in its activities.

The reader will learn not only the functions of insurance seller, his binding characteristics but also a basic insurance risks and subtleties of insurance activities. The textbook "Insurance Services sales process management" is a great tool for anyone interested in insurance business and services provided by insurance - students, insurers, policyholders and others who are planning to engage in insurance activities.

\section{About the Author:}

Daiva JUREVIČIENE - Doctor of Social Sciences, Mykolas Romeris University, Faculty of Economics and Finance Management, Department of Banking and Investments, Professor.

Research interests: personal finances, individual financial behaviour, investments, banking, risk management. 